\title{
Implementation of Corporate Social Responsibility Programs Aimed at HR-Conserving: Russian Metallurgical Companies Case Study
}

\author{
S. Kusov ${ }^{1, *}$, I. Kulkova ${ }^{2}$ \\ ${ }^{1}$ Ural Branch of the Russian Academy of Sciences, Yekaterinburg, Russia \\ ${ }^{2}$ Ural Branch of the Russian Academy of Sciences, Yekaterinburg, Russia \\ *Corresponding author. Email: svk-2007@yandex.ru
}

\begin{abstract}
The article is devoted to the study of corporate social responsibility (CSR) programs as a tool to preserve the health of employees. Conserving human resources is essential for a business, which is why employers invest in keeping employees healthy. Based on the analysis of theoretical approaches to the definition of corporate social responsibility, this article systematizes and analyzes the structure of CSR programs aimed at saving the company's human resources, which includes health improvement of employees, the development of corporate medicine, regular medical examinations, payment of voluntary health insurance, catering in the workplace, promoting sports and healthy lifestyles. The narrative analysis of CSR program components is based on CSR reporting data from leading Russian metallurgical companies: RUSAL, Severstal, EVRAZ, MMK. We also assessed the impact of restrictive measures in countering the spread of the new coronavirus infection COVID-19 on the implementation of CSR programs and its structural elements.
\end{abstract}

Keywords: Corporate social responsibility, healthy lifestyle, staff health improvement, CSR reporting, CSR program structure.

\section{INTRODUCTION}

Saving the human resources is very important for business both in Russia and internationally. The impact of negative environmental factors has serious consequences for the health of workers, including occupational diseases. In turn, the morbidity, trauma and mortality of workers harm labor productivity, increase additional costs, and negatively affect the financial result. A large proportion of workers in metallurgical enterprises work in unfavorable working conditions. The impact of negative environmental factors has serious consequences for the health of workers, including the occurrence of occupational diseases. In turn, the morbidity, trauma and mortality of workers harm labor productivity, increase additional costs, and negatively affect the financial result. Corporate social responsibility (CSR) programs aimed at saving human resources can minimize the impact of harmful factors. The article examines international experience, analyzes the CSR reporting of the leading Russian metallurgical companies.

\section{THE THEORETICAL BASIS OF THE STUDY}

The study is based on the theory of Corporate Social Responsibility by Howard Bowen, developed by R. Freeman and D. Wood. The issues of corporate social responsibility, its definition, structure, significance for people and business are reflected in numerous works of Russian and foreign scientists.

In the paper of Budianto and Suono [1], the thesis is given that CSR is a set of efforts of a company to minimize negative and maximize positive factors in its activities. This thesis quite fully reflects the role of CSR aimed at saving the human resources of companies. Within the framework of the CSR, the company, through the CSR activities, conducts employee health improvement, monitors their health status, engages in sports and a healthy lifestyle, and organizes meals. All these measures reduce negative factors in the form of employee morbidity, mortality and the associated decrease in production and labor productivity, and financial performance. In turn, a positive factor grows in 
the form of loyal employees, labor productivity, good relations with the state and local communities.

M.K.AL Ani in his/her paper indicates that the CSR integrates the social and business activity [2]. This thesis is confirmed by the fact that the social activity of companies, appropriate initiatives in the interests of employees are beneficial to business.

The article by P. Bhardwaj (with co-authors) provides information on the importance of the CSR based on the research results, $50 \%$ of the 29,000 respondents from 58 countries surveyed are willing to pay an increased price for the products of companies investing in the CSR. [3]

The article by Pons, Vintro, Rius and Vilaplana states that business must find compatibility between productivity, environment and social protection. [4] Indeed, these indicators are interrelated. Environmental protection and social security of personnel play an important role in the success of modern business.

The opinion of I.Z. seems quite interesting Rela, who believes that the CSR can be interpreted as corporate moral responsibility to the community in the workplace and in the area of its activity [5]. Also, this author systematizes the theses of previous studies on the role of CSR in the development of society and business and gives the thesis on the essential role of the CSR in social development, sustainable development, and the welfare of society, considering the expectations of stakeholders.

A number of papers indicates the importance of the CSR for the reputation of a business [6], obtaining such significant benefits for business as improving product quality [7], improving relations with government authorities and local communities, consumer loyalty, reducing staff turnover [8], increasing labor productivity, growth of the company's reputation, increasing the investment attractiveness of the company, sustainable development in the long term [9]. In turn, the reputation of a business is important for investors and potential partners.

The CSR programs are actively used in companies whose business is focused on the international market for product sales. [10] In developed countries, the CSR business began to develop quite earlier than Russian practice and became a kind of fundamental phenomenon. If the company is focused on international business, it will be pushed to implement the CSR program, issue the CSR reports, since this can be one of the key conditions for cooperation.

The CSR issues are reflected in the works of Russian and foreign researchers. The theoretical development of this area is performed, its structure and significance for all stakeholders are analyzed: individuals, business, government, and etc. However, at present there is a problem of insufficient number of studies devoted to the impact of the CSR on saving human resources.

\section{STUDY METHODS}

During the study, analytical methods of information processing were used. The authors used the method of narrative analysis of reporting on corporate social responsibility of large metallurgical holdings in Russia, such as:

- United Company RUSAL - a Russian aluminum company, one of the world's largest producers of primary aluminum and alumina;

- Severstal PJSC - a Russian steel and mining company that includes the Cherepovets Metallurgical Plant;

- Evraz Group - an international metallurgical and mining company with assets in the Russian Federation, USA, Canada, Czech Republic, Italy, Kazakhstan, is one of the largest steel producers in the world;

- Magnitogorsk Metallurgical Combine (MMK) - a Russian metallurgical plant in the city of Magnitogorsk, Chelyabinsk Region, one of the largest metallurgical plants in the CIS and Russia.

To identify the components of the CSR programs aimed at saving the company's human resources, a review of literary sources was carried out - publications of Russian and foreign scientists in leading peer-reviewed scientific publications, including international scientific citation systems.

The data on implementation of the components of the CSR programs aimed at saving the human resources of companies and their performance were obtained from the officially published CSR reports of the leading Russian metallurgical companies.

The study of the issue of arranging the employee health improvement and corporate medical services is supposed to be based on the analysis of corporate social responsibility reports of the largest Russian metallurgical holdings in terms of the following aspects:

- availability of its own or outsourced network of medical care;

- investments in development of the health care system;

- $\quad$ spa services;

- impact of the pandemic and arrangement of works in this period.

In the component related to voluntary health insurance, the amount of financing to insurance companies was analyzed. In the component for conducting medical examinations of personnel, 
additional services offered by the employing company were studied, since the legislation of the Russian Federation establishes mandatory primary (upon hiring) and periodic medical examinations at the expense of employers. In the direction of providing workers with food, the initiatives of Russian business were studied. Finally, in the direction of popularizing sports and holding sports events, it was studied what major sports events were held in the companies under study; involvement of employees in sports, including by compensating gym and swimming pool subscriptions; the amount of funds allocated for participation of employees in sports; assistance to sports organizations. Activities aimed at promoting healthy lifestyles and their costs were also studied.

\section{RESEARCH RESULTS}

Based on the analysis of numerous scientific publications by Russian and foreign researchers, it is possible to visually present a diagram of the directions of corporate social responsibility programs aimed at saving the company's human resources (Fig. 1).

The analysis of the sections of the programs on arrangement of employee health improvement and corporate medical services was carried out. This issue is of no small importance in saving the human resources of the enterprise, since in this case there is a possibility of direct influence on the health status of the employee and his/her family members. Some time ago, many Russian enterprises, including city-forming ones, got rid of their own system of medical care, transferring it to state or municipal ownership. The medical departments of enterprises were recognized as non-core assets and were subject to reduction or reorganization. The issue of the effectiveness of this process, as well as the quality of medical care for workers, prevention and diagnosis of diseases, timely detection of occupational diseases, monitoring of the health of workers under the influence of harmful production factors has been and remains highly controversial. The occupational health system was destroyed.
Currently, many leading enterprises in Russia have their own or outsourced health care system for personnel. The annual reports on sustainable development or corporate social responsibility provide data on investments by enterprises in this area. Namely, RUSAL's CSR report [11] refers to the construction of modern high-tech medical centers for treatment of COVID-19 in 7 cities of the Urals and Siberia. After the fight against this disease is no longer relevant, the network of these medical centers will be reoriented to provide medical care to the population, namely, to diagnose complex infectious diseases. To provide medical care, the company selected a highly qualified staff of specialists, and handed over ambulances. Implementation of this direction cost the company more than 4 million US dollars at the end of 2020.

In addition to the above, RUSAL has its own corporate health care system. This function is performed by a structural division of the company - RUSAL Medical Center. Medical organizations of this network are represented in most regions of the company's presence. If it is necessary and there is no possibility of providing some types of medical care, for example, operations, the company covers these costs. In addition, all employees of the company pass the annual medical examinations at this medical organization. The company's employees are provided with free medical care at RUSAL Medical Center. The cost of payments to medical institutions for servicing the company's employees amounted to approximately 449 million rubles in 2020 .

RUSAL's corporate social responsibility measures in terms of improving working conditions for employees and protecting their health, and developing the health care system have yielded good results - a positive trend in reducing the number of occupational diseases: since 2015, by more than $50 \%$.

An important aspect of the direction of employees' health improvement is provision of sanatoriums and health resorts (in addition to social insurance programs).

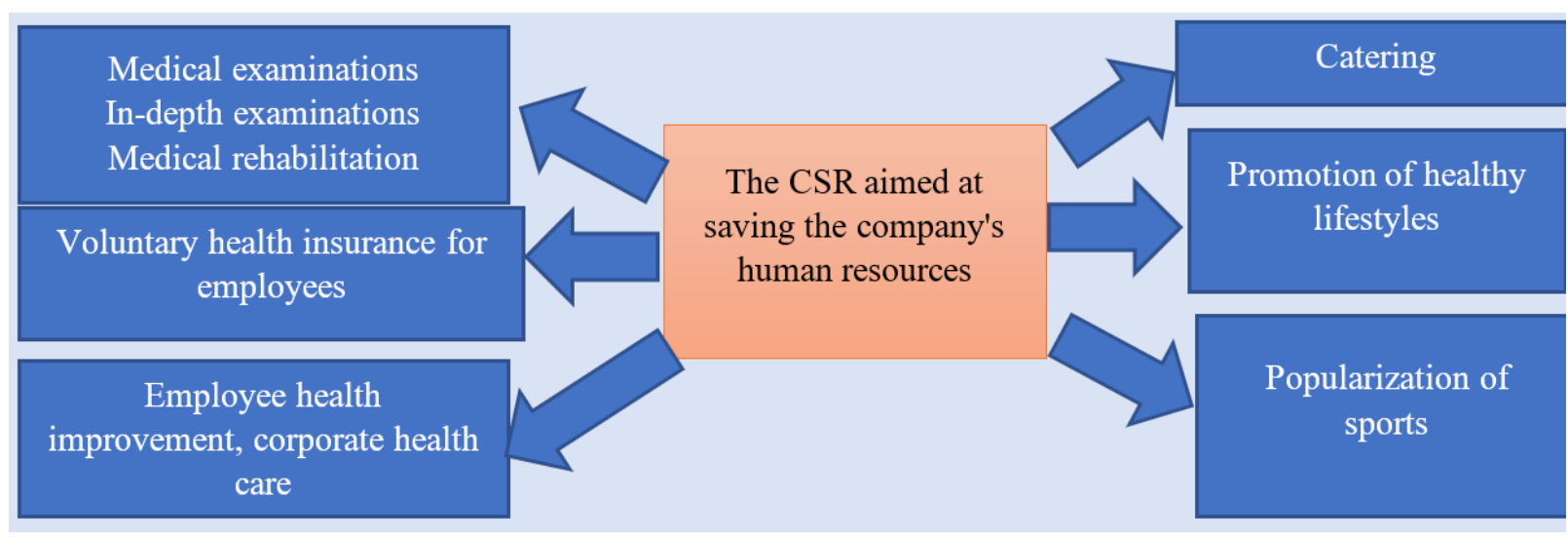

Figure 1 Composition of activities aimed at saving human resources in the CSR programs (compiled by the authors) 
Employees of the company are provided with preferential vouchers to sanatorium-resort organizations located in the territory of the Russian Federation. As a rule, a trip to a sanatorium costs employees no more than $10 \%$ of the cost of the voucher. The trip of the employees' children to the children's camp on vacation costs the employee about $15 \%$ of the cost of the voucher. The company's expenses in this area in 2020 amounted to approximately 28 million rubles.

During the COVID-19 pandemic, RUSAL's medical network focused, among other things, on preventing the incidence of coronavirus among its employees. Employees of the administrative apparatus were, if possible, transferred to the remote work mode. In the absence of such an opportunity, employees were provided with personal protective equipment. The pandemic has made significant adjustments to the company's plans to implement various corporate social responsibility initiatives. All employees of the company were provided with masks and antiseptic agents.

It can be concluded that RUSAL is actively working to implement CSR programs in the area of employee health improvement and organization of corporate medical care.

Consider the CSR initiatives in terms of improving the health of Severstal employees [12]. Employee health is a priority in the company's social activities, and the comprehensive Severstal Health program is being implemented. For the company's employees, medical care has been arranged in its own medical unit in the city of Cherepovets, the services of which cover more than 75 thousand people. In 2020, the company invested more than 25 million rubles in development of the medical unit. In the rest of the territories of the company's presence, medical care of employees is carried out either on its own or with the involvement of local health care institutions, i.e. outsourced.

The company pays $90 \%$ of the cost of vouchers to health resort organizations for employees. Beneficial categories of employees are provided with vouchers free of charge. Also, employees can improve their health on the basis of their own sanatorium. In 2020, 170 million rubles were spent to ensure the recovery of the company's employees. Costs were reduced due to the organization of anti-epidemic measures related to COVID-19. The content of the social sphere is one of the key elements of the company's external social investments.

In order to compensate for the additional costs of employees for purchase of personal protective equipment and medicines, already in the initial period of the pandemic, 10 thousand rubles were paid. In total, about 500 million rubles were spent on arranging these antiepidemic measures. Due to the pandemic and the introduction of restrictive measures, the costs of some of the company's social initiatives have been reduced.
The company is actively working to improve the health of employees in terms of the CSR programs.

Consider the results of EVRAZ's activities in improving employee health and developing corporate medical services based on an analysis of the corporate social responsibility report for 2020 [13].

In 2020, the company allocated USD 2.7 million for the construction of an infectious diseases' hospital in Novokuznetsk, as well as its own metallurgical products for construction of the buildings. The planned results in the report indicate the strengthening of work to protect the health of employees of the company, strengthening of relations with government authorities. In this thesis, one can see the main benefits pointed out by numerous researchers on the issue of corporate social responsibility - improved relations with government authorities and local communities, and a decrease in the incidence of sickness among workers.

In addition, the company allocates funds to support regional healthcare institutions. So, for example, in 2020, the company allocated more than 110 thousand US dollars to support medical organizations, namely, for work on the diagnosis and treatment of COVID-19. The company provides assistance in equipping medical institutions in Nizhny Tagil and Kachkanar.

All facilities of the company are equipped with medical centers. If necessary, payment for medical services is made in third-party organizations. Together with a partner insurance company, a project is being implemented to improve methods for the timely detection of occupational diseases.

Employees of the company are provided with free vouchers to health organizations.

In the context of the COVID-19 pandemic, the company has taken a number of measures to minimize the negative impact of this disease and its consequences on the health of workers: transferring workers to the remote work mode, if possible, providing psychological assistance, developing a mobile application, and conducting post-like rehabilitation in sanatoriums.

Measures to save human resources under corporate social responsibility programs are also implemented by the Magnitogorsk Iron and Steel Works (MMK) [14]. The company annually provides significant financial support to local healthcare institutions, namely, through purchase of modern equipment. This, in turn, has a significant impact on the health of the company's employees, the possibility of taking preventive measures, and timely detection of occupational diseases.

In the reporting year, the company spent more than 4 million US dollars to provide sanatorium and resort services to its employees, 9,141 people were rehabilitated. The company finances up to $85 \%$ of the cost of a voucher to MMK's sanatoriums and rest homes. 
In the context of the COVID-19 pandemic, the company carried out a number of preventive measures: transferring some employees to remote work whenever possible, revising the schedules of other employees, conducting vaccinations, conducting express testing, and regularly disinfecting the premises.

Organization of work on voluntary health insurance (VHI) of employees is a very important element of the company's CSR program, its social guarantees for employees. In addition, it is a significant element of financing activities for improvement of employees in their own corporate health care network and third-party organizations, the social package of employees.

Consider the results of the companies' work in this area, as reflected in the CSR reports for 2020. Medical examinations and treatment of employees are carried out for RUSAL employees at the expense of VHI funds. Obtaining VHI policies is included in the program of Social guarantees for the company's employees. The costs of arranging the voluntary health insurance for the company's employees amounted to 241 million rubles in 2020 .

Providing employees with VHI policies is an important element of Severstal's social spending. The voluntary health insurance is one of the instruments for financing the activities of health centers of some divisions of the company. Employees actively use VHI programs. In some divisions, about $54 \%$ of employees took advantage of the treatment under the VHI policy.

Voluntary health insurance is included in the social package for EVRAZ employees. VHI policies cover 100 $\%$ of MMK employees.

Carrying out medical examinations of employees is a very important element of CSR programs aimed at saving the company's human resources. In conditions of exposure to harmful production factors, medical examinations of employees are mandatory and annual. This is regulated by order of the Ministry of Health of the Russian Federation No. 29-n dated January 28, 2021.

RUSAL employees undergo medical examinations in their network of medical centers. Medical examinations are carried out free of charge for employees as part of the corporate VHI program. Employees of some territories where Severstal operates undergo medical examinations at their own medical organizations.

In addition to the standard medical examination procedure, EVRAZ is working with a partner insurance company to implement a continuous medical monitoring project. By analyzing data, you can identify and minimize medical risks, prevent and treat diseases at an early stage.

At MMK, employees have the opportunity to undergo regular medical examinations and participate in health programs. Medical examinations are carried out on the basis of our own medical department. To minimize the time required for medical examinations, the company is implementing an automated system. As a result, the number of identified occupational diseases decreases.

Do not forget that in general, the level of development of health care affects the state of human health by about 10-15\%. Habitat, lifestyle, nutrition, etc. are extremely important influencing aspects. Consider the factors that a company can influence through corporate social responsibility programs.

Providing food at the workplace is of no small importance in ensuring of saving the health of employees of the enterprise. Companies are aware of the importance of this area and this issue is reflected in corporate social reporting. Let's consider the initiatives of large representatives of Russian business in terms of the implementation of these initiatives. For example, all RUSAL employees receive a full meal subsidy every shift. In addition, almost all enterprises receive 0.5 liter of milk per shift free of charge for workers involved in production. This is one of the corporate social support measures.

MMK's report contains a thesis on arrangement of healthy meals for employees. The expenses for catering for employees have a significant share in the structure of the company's social expenses at the end of 2020.

According to Severstal's CSR report, it also pays attention to catering for employees. Workers visit the factory canteens, and where this is technically impossible, eating rooms are arranged. In addition, the company reimbursed personal expenses for catering during the pandemic by calculating a single compensation payment.

EVRAZ has modernized several canteens, and is also considering the possibility of compensating workers for arranging meals when working remotely in the context of the COVID-19 pandemic.

Further, such an important aspect of corporate social responsibility aimed at saving the company's human resources, such as the popularization of sports and the holding of mass sports events, was analyzed.

Arrangement of sporting events is one of the ways to interact with personnel, as reflected in the RUSAL CSR report for 2020. Employees are given the opportunity to exercise free of charge and participate in sports activities. The company annually pledges expenses to compensate employees for visiting gyms in the corporate budget. Arrangement of sports activities for employees is one of the important areas of social investment in the company. According to the company's CSR report, the cost of promoting sports amounted to $2.3 \%$ of the scope of social investments. In monetary terms, this amounted to approximately USD 1.4 million. In relations with local communities, it is also important to focus on 
development of appropriate infrastructure and popularization of skiing. The project "On skis" is being implemented together with other interested parties. The project finances the development of skiing infrastructure, purchases equipment. In the reporting year, snow groomers were purchased in the amount of 82.1 million rubles. Contests, championships, master classes are arranged. Competitions of professional skills and a scholarship program for ski trainers have been organized. In addition, assistance is provided to other sports organizations in the territories of the company's presence. Implementation of these initiatives of the company, in addition to having a positive effect on the health of employees, has a positive effect on its reputation, relations with the state and local communities. In turn, this affects the conditions and environment for the functioning of the business, its effectiveness.

The sports organization is also covered in the CSR report of Severstal for 2020. The company has arranged a corporate sports movement "Severstal no limits". Sports events are held. The costs of sporting events are budgeted for by the company for social personnel costs. The company is interested in the maximum involvement of employees in physical education and sports. Employees are provided with a $50 \%$ discount on access to the pool and gym. The Severstal Russian Steel Spartakiad is held annually. In addition, many championships are held in other sports. In 2020, $29.6 \%$ of employees of the Cherepovets Metallurgical Plant, which is part of the company, were involved in full-time sports. In addition, the company has its own sports facilities, and also finances the construction of sports facilities.

EVRAZ's CSR report for 2020 also reflects the company's performance in this area. The company arranges sports events for employees and their families. Significant funds are allocated for this annually. The company also invests in construction of sports facilities. Carrying out these measures, according to the company, minimizes the impact of various risks, both socioeconomic and deterioration of relations with the state and local communities. Social expenditures related to popularization of sports amounted to USD 7.9 million in 2020.

The Magnitogorsk Iron and Steel Works (MMK) is also doing a lot to popularize sports and hold sports mass events, which is reflected in the CSR report for 2020. According to the results of the reporting year, the company held 218 sports events. At the end of 2020, approximately USD 1.5 million was spent on activities related to the promotion of a healthy lifestyle and development of sports. Assistance in development of sports is one of the areas for development of relations between MMK and local communities.

An important direction of the CSR companies' activities aimed at saving the company's human resources and related to the popularization of sports is the promotion of the healthy lifestyle. This issue is also reflected in the CSR reporting.

RUSAL is actively involved in promoting healthy lifestyles among both employees and local communities. This event in 2020, together with sports funding, $2.3 \%$ of the company's social spending budget (approximately USD 1.4 million) is allocated.

At Severstal, promoting the healthy lifestyle among employees is also a priority.

EVRAZ is actively involved in promoting healthy lifestyles, especially among young employees. Namely, a skate park has been set up in the village of Valerianovka to promote the healthy lifestyle. The Ural division is implementing a program aimed at promoting the healthy lifestyle. In the future, the experience will be extended to other areas of the company's business.

MMK strives to make a significant contribution to promotion of the healthy lifestyle. In the structure of the company's social programs, programs for the healthy lifestyle are being implemented for employees. At the end of 2020, these events, in conjunction with the popularization of sports, were spent about a million US dollars.

\section{CONCLUSION}

This article analyzes the CSR reporting of the leading Russian metallurgical companies, describes and evaluates measures to save human resources.

When analyzing reports on corporate social responsibility of companies, it was revealed that the scope of investments in arrangement of employee health improvement and development of the corporate medical service system, as well as the significance of these aspects, are quite serious for business. It is emphasized that a person and his/her state of health are important for functioning and future development of the company. Enterprises have both their own health care system, but also cover the costs of services in other clinics, if necessary. A number of companies finance the construction of new hospitals in the territories of their presence, equipping them with modern equipment and attracting highly qualified personnel. This has a significant positive effect when interacting with government authorities and local communities. Some companies, in collaboration with partners, are developing systems for medical monitoring and timely detection of occupational diseases.

Voluntary health insurance is a good tool to influence the saving of human resources of the company, allowing enterprises to finance appropriate activities and employees to receive quality medical care [15]. The companies considered in our study include VHI policies in the social package of employees, which increases their 
attractiveness as an employer. The possibility of obtaining additional services under the VHI policy can facilitate the receipt of medical services of a higher quality, carry out prevention, in-depth diagnostics and treatment. This has a positive effect on the health of employees and on the saving of the company's human resources.

When analyzing the arrangements for catering for employees, as reflected in corporate social reporting, one can single out general points: meals are arranged for employees at the workplace; compensation may be provided for the employee for related costs.

Summarizing the analysis of the company's activities in terms of popularizing sports, the following conclusions were made:

- companies encourage and finance employees' physical education and sports activities, increasing their involvement;

- $\quad$ in addition to the maintenance of their own sports facilities, the construction of new facilities in the territories of presence is financed;

- $\quad$ significant sums for this direction are included in the annual budgets;

- companies arrange annual sports mass events, but their number has slightly decreased as a result of the COVID-19 pandemic;

- the reports of some companies reflect the focus of these expenses, including on improving relations with the state and local communities.

Sports and a healthy lifestyle by employees have a positive impact on saving the human resources. In addition, employee loyalty and engagement are increased. Business is aware of this and this direction is reflected in the plans of social events of the companies, as well as in the reports on corporate social responsibility.

Therefore, the business not only finances events within its own corporate environment (development of corporate medicine, medical examinations, providing employees with VHI policies, food, involving employees in sports and maintaining a healthy lifestyle), but also invests in the development of the territories of its presence (construction and equipping the hospitals, sports facilities, mass sports events, assistance to medical institutions, assistance to family members of employees). This is the essence of the CSR as additional measures taken by business to improve the quality of life of its employees and society as a whole. In turn, business receives certain benefits: good relations with the state and local communities, loyalty of employees and consumers, increased labor productivity, and etc.

\section{ACKNOWLEDGMENTS}

The article is carried out in accordance with the research plan of the Institute of Economics of the Ural Branch of the Russian Academy of Sciences.

\section{REFERENCES}

[1] R. Budianto, E. Suyono, Corporate social responsibility and factors affecting it: An empirical evidence from the Indonesian capital market. In: International Journal of Economics and Business Administration, 8(1) (2020) pp. 239-253.

[2] Mawih Kareem AL Ani. Corporate social responsibility disclosure and financial reporting quality: Evidence from Gulf Cooperation Council countries. Borsa Istanbul Review 21-S1 (2021).

[3] P. Bhardwaj, P. Chatterjee, K.D. Demir, O. Turut, When and how is Corporate social responsibility profitable. In: Journal of Business Research, 84 (2018) pp. 206-219.

[4] A. Pons, C. Vintro, J. Rius, J. Vilaplana, Impact of Corporate social responsibility in mining industries. In: Resources Policy, 72 (2021) pp. 102-117.

[5] I.Z. Rela, A.H. Awang, Z. Ramly, M. Rusdan, M. Mappasomba, A. Nikoyan, Conceptual model of Corporate social responsibility impact on community well-being. In: Entrepreneurship and sustainability issues, 8(2) (2020).

[6] P. Boring, The relationship between firm productivity, firm size and CSR objectives for innovations. In: Eurasian Business Review, 9 (2019) pp. 269-297.

[7] T.A. Pikalova, Corporate social responsibility of the backbone companies of the mining and metallurgical industry in Russia. In: Zapiski Gornogo instituta, 206 (2013).

[8] Jh.A. Frantsevich, Formation of a rational system of corporate social responsibility of a coal company. In: Mining information and analytical bulletin, 3 (2007) pp. 135-140.

[9] M.M. Basova, Analysis of social aspects of industrial enterprises. In: Naukovedenie Internet magazine, 7(2) (2015).

[10] N.S. Ofogbe, C.N. Ezuwore-Obodoekwe, A.P. Ozoji, C. Nnamani, C.A. Anisiuba, P. Ojiakor Ijeama, Regina Okafor, Impact of environmental, social and governance dimensions of corporate social responsibility on firm performance: evidence from Nigeria. In: Humanities and Social Sciences Letters, 9(2) (2021) pp. 220-236.

[11] RUSAL Corporate Social Responsibility Report 2020. 
[12] Severstal Corporate Social Responsibility Report 2020.

[13] Evraz Corporate Social Responsibility Report 2020.

[14] Corporate Social Responsibility Report of Magnitogorsk Iron and Steel Works for 2020.

[15] S. Kusov, The impact of Corporate Social Responsibility programs on preserving the health and Prolonging the employees' working longevity In: Human Progress, 7(3) (2021) pp. 9. 